\title{
Comments on the ophiuroid family Protasteridae and description of a new genus from the Lower Devonian of the Fox Bay Formation, Falkland Islands
}

Hunter, A.W., Rushton, A.W.A. \& Stone, P. 2016. Alcheringa, Volume 40 (Part 4), 429-442. http://dx.doi.org/10.1080/03115518.2016.1218246

\begin{abstract}
:
Asterozoan fossils are comparatively rare in Gondwana compared with Laurentia, especially in the Devonian. We examined the only fossil ophiuroid yet known from the Falkland Islands and assess its significance for the evolution of the clade. This ophiuroid, herein distinguished as new genus and species, Darwinaster coleenbiggsae, belongs to the same suprageneric group as Protaster, which was established on a series of Middle-Upper Ordovician taxa and persisted into the late Palaeozoic remarkably little changed in morphology. This single example is part of a much wider fauna that includes fossils from the Bokkeveld Group, South Africa and the Precordillera of Argentina. Existing palaeobiogeographic reconstructions confirm that these faunas once existed on contiguous terranes and characterized a distinct suite of similar palaeoenvironments within the Malvinokaffric Realm. This study reviews the existing record of Devonian asterozoans and revises the family Protasteridae.
\end{abstract}

Aaron W. Hunter [aaron.hunter@curtin.edu.au], Department of Applied Geology, Western Australian School of Mines, Curtin University, GPO Box U1987, Perth, WA 6845, Australia; \& Department of Earth Science, University of Cambridge, Downing Street. Cambridge, UK. Adrian W. A. Rushton [a.rushton@nhm.ac.uk], Department of Earth Sciences, The Natural History Museum, Cromwell Road, London SW7 5BD, UK; and Philip Stone [psto@bgs.ac.uk], British Geological Survey, The Lyell Centre, Research Avenue South, Edinburgh, EH14 4AP, UK. 